\title{
Using GIS Tools and Data for Hydrological Modelling in Arid Areas: A Literature Review \\ Dr. Hassan M. Khormi
}

Department of Social Science, Arts and

Humanities College, Jazan University,

Saudi Arabia.

hkhormi@jazanu.edu.sa

Received on 3/10/2018

Accepted on 21/11/2018 


\section{USING GIS TOOLS AND DATA FOR HYDROLOGICAL MODELLING IN ARID AREAS: A LITERATURE REVIEW \\ Dr. Hassan M. Khormi \\ Department of Social Science, Arts and \\ Humanities College, Jazan University, \\ Saudi Arabia. \\ hkhormi@jazanu.edu.sa}

\section{Abstract}

This study reviews a number of hydrological modelling studies in arid areas, including the use of spatial analysis in geographical information systems (GIS) and remote sensing (RS) packages. Specifically, it aims to review the most important GIS tools and spatial data used in modeling processes. We discuss the use of digital elevation model data, land-use/cover data, soil data, and rainfall data in terms of their impacts on applications of hydrological modelling. The review concentrates on commonly used tools, e.g., the soil and water assessment tool, the kinematic runoff and erosion model, the identification of unit hydrograph and component flows from rainfall, the evaporation and stream flow model, and the Hydrologic Engineering Center-Hydrologic Modelling System. The runoff curve number method is illustrated as an example of methods that are utilized in GIS-based hydrological models. Arid areas require more attention from researchers in order to overcome the obstacles to hydrological modelling identified in the study. For example, they should consider new methods for determining spatial rainfall and infiltration from transient flows that come from flash floods. Instead of using gauged data on arid areas, RS data can be used for simulating events. Observational data can also be improved by creating multiple measurement stations in affected areas.

Keywords: Digital Elevation Model, Spatial Information Technology, Hydrological Modelling, Arid Areas, and SWAT

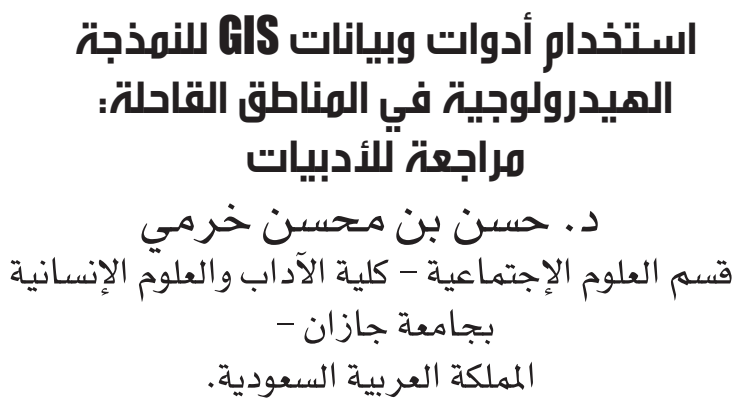

hkhormi@jazanu.edu.sa

ملخم الدراسة

تستعرض هذه الدراسة عددا من البحوث والدراسات

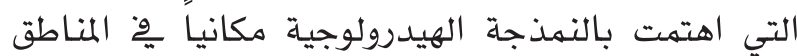

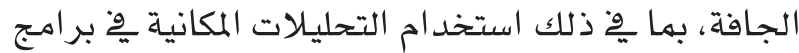

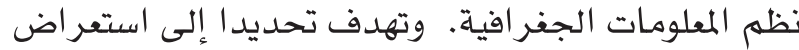
أهم ادوات نظم المعلومات الجفرافية والبيانات المكانية

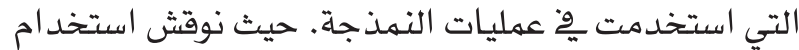

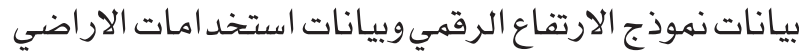

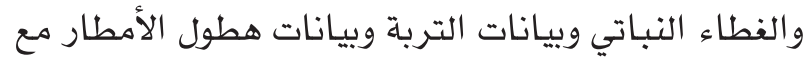
تقصيل لتأثيرها على تطبيقات النمذجة الهيدرولوجية.

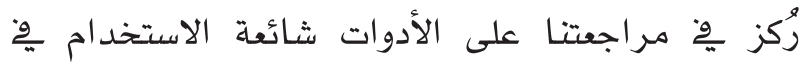

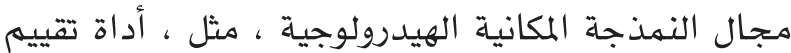
التربة والمياه ، نموذج الجريان الحرارى ونموذج التآكل السطحي، تحديد وحدة الهيدروغراف ومكونات التدفق التقان من نموذج تدفق الأمطار ، والتبخر والتيار ونظام مركز لهرئراف ومكات الهيدرولوجيا الهندسية، والنظام الهيدرولوجى للنمذجة.

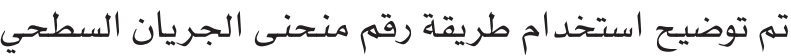

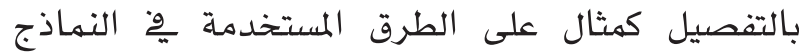
الهيدرولوجية القائمة على نظم المعلومات الجفرافية.

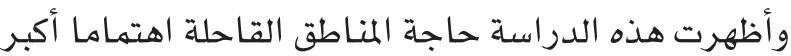
من الباحثين من أجل التغلب على العقبات التي تم تقصيلها عْ هذه الدراسة والخاصة بالنمذجة الهيدرولوجية. على الى

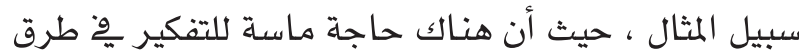
جديدة لتحديد مستوى هطول الأمطار والتسلل المكاني من

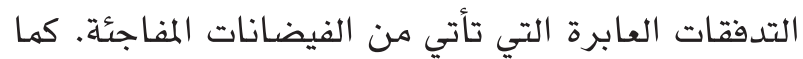

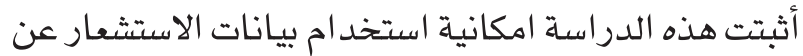

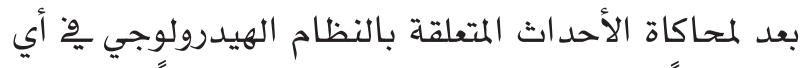
مكان بدلاً من استخدام البيانات المقاسة ميد المياً.

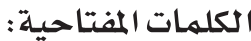
نظم المعلومات الجفرافية، النمذجة الهيدرولوجية، المناطق الجافة ، تقييم الترية والمياه. 


\section{Introduction}

The significant demand for water resources, along with the associated current and future environmentalissues, haveled to growing concerns regarding the prediction and understanding of the natural process of this situation. Several models have been developed to simulate hydrological systems, from precipitation to streamflow (Beven, 2001). With the rapid advancement of computer technology, geographic information systems (GIS) and remote sensing (RS) have played a fundamental role in developing these hydrological models (Wilson et al., 2000). RS technology has improved the availability of data, and GIS is a powerful tool that processes several kinds of data. Furthermore, GIS has the capability to provide improved and clearer visualizations.

Several studies have been carried out with the aim of analyzing and modelling hydrological systems (Wheater et al. 2008). Most of these studies have presented hydrological models and categorized them according to their complexity, data availability, and user requirements. Furthermore, numerous studies have been conducted to explore the linkage between hydrological models and advanced technology, such as GIS and RS. One of the most comprehensive studies in this field was undertaken by Ogden (2001). This study provided a detailed description of hydrological models and applications, including GIS features for watershed analysis and hydrological modelling. Another study on RS data applications in hydrological modelling was presented by Kite et al. (1996). However, despite their usefulness, most of these studies developed several efficient models that were only suitable for humid environments (Pilgrim et al., 1988).

Due to the harsh climatological and physical conditions in arid areas, a limited number of studies have been carried out on this topic (Wheater et al., 2008). For example, Al-Turbak
(1996) used a geomorphoclimatic model in three arid watersheds in Saudi Arabia to calculate rainfall intensity. Another study in Oman was carried out by Al-Qurashi (2008), who applied a distributed, physically-based rainfall-runoff model to predict event hydrograph features in a catchment area.

The present study reviews a wide range of literature related to hydrological modelling in arid regions, including the use of GIS and RS technology on hydrological and watershed models. The combination of data, such as digital elevation model data, land-use/cover data, soil data, and rainfall data, will be discussed in detail regarding their role in hydrological modelling applications. The soil and water assessment tool (SWAT), the kinematic runoff and erosion model (Kineros2), the identification of unit hydrograph and component flows from rainfall, evaporation, and streamflow (IHACRES) model, and the Hydrologic Engineering CenterHydrologic Modelling System (HEC-HMS) are all examples of hydrological models that have been successfully used in some studies in arid regions. The runoff curve number $(\mathrm{RCN})$ method is illustrated as an example of a method used in GIS-based hydrological models.

\section{Methodology}

World-famous databases were used to procure various types of articles, academic papers, dissertations, documents, and studies related to hydrological modeling in arid regions, including those employing GIS and RS technology for hydrological and watershed models. These databases were ABS Statistics, BioOne, CSA, Current Contents, Emerald, Gale databases, Hein Online, Informit, JSTOR, Science Direct, Scopus, SpringerLink, Taylor and Francis, Web of Knowledge, and Google Scholar. In order to use these databases to conduct searches for studies, articles, research, and other literary reports, 
a number of keywords were used or tagged together or differently. These keywords included hydrological modeling, hydrological modeling and arid areas, GIS for hydrological modeling, watersheds and modeling, remote sensing and precipitation, climate factors for hydrological modeling, soil and runoff, moisture and runoff, erosion, runoff and hydrogeological modeling in geographical areas, spatial techniques, GIS, hydrological modeling of engineering, dry areas and watersheds, and remote sensing data for watershed and watercourse extraction.

\section{Hydrological models}

Hydrological models are mathematically based and can be defined as conceptual representations of the hydrological system (KITE, 1996). The primary use of hydrological models is to simulate the hydrological system from precipitation to streamflow for the purpose of prediction and understanding of the hydrologic process (Reed et al., 2007). There are different kinds of hydrological models, varying from simple to sophisticated. Simple models are "mainly based on data and the use of mathematical and statistical concepts to link a certain input to model an output." A more complex model, also called a physically-based model, produces three-dimensional simulations of a watershed (KITE, 1996).

Hydrological models are used to study the runoff process. Over the years, there have been many attempts to simulate and generate the runoff process, such as the black-box technique (Chow et al., 1988). However, this technique leaves out vital information about hydrological processes that generate runoff. The black-box technique was followed by a "Period of Rationalization" when three methods coincided - the unit hydrograph method, Richard's equation for unsaturated flow, and Horton's work on infiltration and the production of runoff (Chow, 1964). Another approach was advanced by Engman (1986), who gathered many internal processes, turning the black-box technique into a computer-based model. However, some of these system states were estimated states, which can influence the results of the process. Other studies have mainly focused on understanding the streamflow generation process using infiltration and the determination of taking effective rainfall into account. Kirkby (1978) proposed using several runoff-generation methods to develop a more realistic approach to modelling runoff generation. These methods included infiltration-limited overland flow, partial area overland flow, saturation excess overland flow, sub-surface stormflow, and saturated wedge flow (Wood et al., 1990).

With advancements in technology, deterministic hydrological models were developed. They fall into two main categories - lumped and distributed models. The watershed in lumped models is expressed as a single entity with a single rainfall input. Lumped models require limited data to be applied to the watershed. However, this can compromise the model resolution. Examples of the most popular lumped models include the identification of unit hydrographs and component flows from rainfall, the evaporation and streamflow data (IHACRES) model (Jakeman and Hornberger, 1993), the Australian water balance model (AWBM) (Boughton and Chiew, 2007), the GR4J model (Perrin et al., 2003), and the North American mesoscale model (NAM) (DHI, 1993). In recent years, some models have been developed that closely represent observed hydraulic phenomena.

This has led to more advanced distributed models in which watershed is broken down into smaller areas. According to Beven (2001b), "distributed models make predictions by discretizing the catchment into a large number of grid squares." Examples of grid models include SWAT (Arnold et al., 1998b), TOPMODEL (Beven et al., 1995), 
and the hydrologic modelling system (HECHMS) (Scharffenberg and Fleming, 2010). By contrast, distributed models require a great amount of conventional hydrometeorological and spatial data in order to run (Abushandi, 2011).

\section{Hydrological modelling in arid areas}

The sub-tropics have the most arid zones in the world. The relationship between rainfall and reference waterdemand is the basis for determining the degree of aridity and can be used to divide arid zones into several sub-categories (De Pauw et al., 2000). In arid regions, hydrologists cannot use hydrological models efficiently due to the harsh climatic conditions and the lack of quality data (Al-Qurashi et al., 2008; Beven, 1984; Bronstert, 2004; McIntyre and Al-Qurashi, 2009; Pilgrim et al., 1988). They also conclude that disrupted models cannot give an accurate representation of reality, that is, the "full picture of reality." This can intensify the dilemma of harsh weather conditions and quality data deficiency in arid areas. For example, flow measurement of flash floods is difficult to predict for several reasons, such as the harsh climatological and physical arid conditions, a lack of suitable natural control sections in streams with movable beds, the high cost of artificial control, limited access in rainy seasons, and the possible damage of instruments by rocks and sediment loads (Pilgrim et al., 1988).

A limited number of distributed models have been developed or modified for arid environments. Al-Turbak (1996) calculated rainfall intensity and duration by using physically-based infiltration components in a geomorphoclimatic model in three arid watersheds in Saudi Arabia. According to the study, the model successfully reproduced surface runoff hydrographs for areas in which detailed and accurate data were available.

Another study was carried out by Al-Qurashi (2008) in Oman. It applied a distributed, physically-based, rainfall-runoff model (Kineros) to 27 rainfall-runoff events from arid catchments. The model was used to predict the features of the event hydrographs in the catchment area. Al-Qurashi (2008) stated that the rainfall-runoff model could mainly be used in arid areas to represent spatially distributed surface topography and/or rainfall and to simulate spatially distributed runoff. The study concluded that the dataset used for the rainfall-runoff model produced inaccurate results when it was used in arid areas. There are many explanations for this conclusion, such as limited observation and the lack of calibration of key surface and subsurface parameters.

A GIS-based Soil Conservation Service curve number (SCS-CN) approach was developed by Shadeed and Almasri (2010). This approach was used to calculate the combined $\mathrm{CN}$ of West Bank catchments in Palestine. They managed to use their results to prove the applicability of the GIS-based SCS-CN approach for that region. However, the authentication of the validity of the developed approach was limited due to the insufficiency of rainfall-runoff records.

\subsection{Hydrological and watershed models in geographic information systems and remote sensing technology}

Hydrological modelling has been strongly influenced by advancements in GIS and RS technology. RS technology has improved the availability of hydrological data, while GIS is a powerful tool that has the ability to process several kinds of data, such as vector and raster data. Moreover, GIS is able to represent georeferenced data, thus enabling the overlaying, merging, and visualization of data (Lu, 1996). Jain et al. (2004) stated that GIS technology reduces estimation time, manages and analyzes huge databases that show characteristic landsurface diversity, and improves the presentation of model results. Merging these technologies has resulted in simplified, effective distributed 
hydrological modelling (Lu, 1996).

Several studies have described the use of GIS in hydrological modelling (Zhang et al., 1990; Lee and Terstriep, 1991; Tim et al., 1992; Bhaskar et al., 1992; Maidment, 1993; Frederickson, 1993; Srinivasan and Engel, 1994; Brennen, 1994). A detailed description of RS theory and application in hydrology was presented by Rango (1994). Another study conducted by Tim (1995) explained the impact of advanced GIS and RS technologies on hydrological modelling.

Recent progress in RS technology has improved the availability of acquiring data in an efficient and timely manner. Examples of these technologies include radar systems, such as the next-generation radar (NEXRAD) and the Weather Surveillance Radars-88 Doppler. These systems have the ability to provide near real-time and high-resolution data for spatial and temporal rainfall volumes and intensity (Singh and Woolhiser, 2002; Vieux, 2004). For distributed models, this format of rainfall data has proven to be extremely functional. In the San Antonio River Basin, Knebl et al. (2005) used NEXRAD rainfall data and HEC-HMS to perform regionalscale flood modelling during a 2002 storm event. Furthermore, Moon et al. (2004) verified that by using NEXRAD rainfall input in place of rain gauge inputs, the estimation of streamflow improved in the SWAT model.

Satellite imaging data were initially used by researchers to extract land-use/cover information. These data were integrated with GIS to simulate runoff, infiltration, evaporation, erosion, and sedimentation studies (Young et al., 1987; Johnson, 1989; Jakubauskas et al., 1992; Kouwen et al., 1993; Ross and Tara, 1993). In eastern India, Shrivastava (2004) presented a study that integrated the SWAT model with RS data and GIS techniques and then verified the viability of the integrated system. Furthermore, the model was used to examine its ability to estimate the runoff and sediment yield from a small watershed. GIS tools were used by Shrivastava (2004) to extract information from different map layers, such as land use/cover, the digital elevation model (DEM), soil, slope, drainage, and watershed and sub-watershed borders, as well as to input these data into the SWAT model.

Another study of satellite imaging was performed in the United States. Advanced Very High Resolution Radiometer and Geostationary Operational Environmental Satellites were employed to generate maps showing snow cover in 4,000 river basins, which could contribute to the waterflow in the local watersheds during warm weather (NOAA, 2008). Other sources, such as the System for Earth Observation satellite and the Landsat satellite, have provided models for extracting the data required to map and classify soils and land use/cover (Vieux, 2004).

\section{Digital elevation model}

ADEM is used to represent the spatial distribution of elevations and depends on a geodetic datum as a systematic display of numbers. Some elevations in the DEM can be sampled at discrete points. Others can be an average elevation over a specific section of the site. DEMs are considered to be a sub-class of digital terrain models (DTMs), which are a systematic display of numbers that represent the spatial distribution of topography characteristics (Moore et al., 1991).

More recently, geoscientists have used DEM data for hydrology studies, topography analyses, and other natural studies (Dewan et al., 2004). When comparing field surveys and elevation data from stereophotographs and the process time of these data, DEM data are more effective (Tribe 1992). Therefore, most geoscientists rely on DEMs produced by organizations or companies. Generally, DEMs are produced from different sources such as contour maps, aerial photographs 
(digitized elevations and photometric stereo models), and RS images (Garbrecht et al., 2000).

\subsection{Structure of digital elevation model data}

There are three DEM data structures: (1) Triangulated irregular networks are vector-based representations of land surface that form an irregular network of points and lines with threedimensional coordinates $(\mathrm{x}, \mathrm{y}$, and $\mathrm{z})$ together with pointers to their neighbors in the net (Peucker et al., 1978; Mark, 1975). (2) Contourbased networks require "an order of magnitude [of] more data storage and do not provide any computational advantages" (Moore, 1988). (3) The most extensively used DEM structure is the raster (square-grid) network, which is defined as a matrix of square grids, with each cell elevation stored in a two-dimensional array. The location of the row and column cell within the array provides the location of a cell in the geographic space. There are several advantages and disadvantages associated with this structure. A square-grid network is simple; the processing is functional; and the computation is efficient. The disadvantages include difficulty handling sudden elevations and an unrealistic representation of the computed upslope flow paths used in hydrologic analysis. Computational efficiency and results are affected by the size of the grid network (Panuska et al., 1990) and the lack of accuracy in determining the catchment area.

\subsection{The use of the digital elevation model in hydrological modelling}

There are many hydrological applications for which DEMs have been used, such as in deriving slope, aspect, and hill-shaded maps and in the computation of wetness indices, etc. DEMs are used to observe drainage-related features such as ridges, valley bottoms, channel networks, and surface drainage patterns. They are also used to measure properties for subcatchments and channels such as size, length, and slope. Both the quality and resolution of DEMs are responsible for accuracy in this topographic information (Garbrecht et al., 2000). DEMs have been used in hydrological modelling in many different ways. For example, for the purpose of assessing the pattern of potential soil moisture and changes in soil texture caused by the erosion process, DEMs were used by O'Loughlin (1986) and Schmidt and Persson (2003) to obtain indices for potential flow accumulation and wetness. Moreover, flow channels acquired from DEMs were used for the delineation of watersheds, the estimation of upslope areas (O'Callaghan and Mark, 1984; Jenson and Domingue, 1988; Reiger, 1998), and for flow routing (Quinn et al., 1991).

\section{Data Use in Hydrological Modelling}

\subsection{Land-use/land cover data}

Land cover is defined as the natural surface of the earth, including vegetation, soil, and water. Land cover also includes human structures and yield. Land use indicates the human use of land, such as settlement and modification of the natural environment and the effect on the land cover (Fresco, 1994; McConnell \& Moran, 2001).

Surveys and census data are a commonly used source of land-use/cover data. Statistical information on land use can be provided by countries and international agencies for environmental studies. Another source of landuse/cover data is RS technology. Both supervised and unsupervised classification methods are used to analyze the remotely sensed digital images, which are then classified into different land-use types (Gunduz, 2003).

In hydrological modelling, land-use/cover data are used to provide an assessment of the roughness or resistance of the land, which affects the water flow motion. Land-use information is used to measure the amount of rainfall infiltration on a surface. In addition, land-use data and 
the soil characteristics of a land surface can be combined to calculate percolation and waterholding capacity values (ASCE, 1999).

\subsection{Soil data}

Soil data are an essential component of hydrologic modelling. Certain soil data are required for most hydrologic cycles, such as soil type, porosity, and hydraulic conductivity. Soil data can be extracted from soil survey maps or RS images, which have to be processed by supervised or unsupervised techniques to obtain soil types (Gunduz, 2003).

\subsection{Rainfall data}

In hydrological modelling, rainfall data are considered essential. Hydrological model calibration and verification depend on highquality rainfall and runoff data. The most highly available and reliable form of data for hydrologic modelling applications is rain gauge data. Moreover, several types of data are important for hydrological applications in evaporation studies; for example, temperature data are used to measure potential evapotranspiration (Gunduz, 2003).

\section{The Use of the Soil and Water Assessment Tool in Hydrological Modelling in Arid \\ Regions}

Many hydrological models can be used to delineate watershed systems; however, as stated earlier, the categories of these models differ. The SWAT model has been used successfully in studies in semi-arid and arid regions. Some of these studies include Al Mulla (2005), Schneider (2007), Ouessar et al. (2009), and Fadil et al. (2011). SWAT has a GIS interface for ESRI ArcView. In every study area, SWAT has the capability to simulate hydrological processes and transmission losses.

\subsection{Soil and water assessment tool model description}

The SWAT model was initially developed to assist the United States Department of Agriculture (USDA) and the Agriculture Research Service (ARS) in their research (Neitsch et al., 2002). The development and modification of SWAT took over 30 years. A number of USDA-ARS models have been integrated with SWAT, such as the model for Chemicals, Runoff, and Erosion from Agricultural Management Systems (Knisel, 1980); the Erosion Productivity Impact Calculator (Williams et al., 1984); and the Groundwater Loading Effects on Agricultural Management Systems (Leonard et al., 1987). The Simulator for Water Resources in Rural Basins (Williams et al., 1985; Arnold et al., 1990) model is considered to be the foundation of the SWAT model.

The SWAT model is a physically-based, semidistributed, and continuous time model that runs to simulate watershed practices. Model components include hydrology, weather, sedimentation, soil temperature, crop growth, nutrients, pesticides, and agricultural management. SWAT works in large, complicated watersheds to predict the impact of land-use management on water, agricultural crops, and sediment. The simulation of hydrological processes includes using the SCS$\mathrm{CN}$ and infiltration equation (Green and Ampt, 1911) to compute the surface runoff, simulating the canal of subsurface flow, generating streams of groundwater flow from shallow aquifers, and estimating potential evapotranspiration, transmission losses from streams, and water storage and loss from reservoirs. Based on monthly climate statistics, the variables can be provided as inputs. Moreover, the SWAT model can be used to generate weather data or to fill in gaps in measured records through the WXGEN weather generator model (Sharpley and Williams, 1990). The modified universal soil loss equation can compute the sediment yield for each sub-basin. Crop growth can be simulated, and soil temperature can be modelled in layers. 
Irrigation and withdrawals from the system can be represented by simulating water diversions.

4.2 The soil and water assessment tool ArcView interface

The SWAT ArcView interface (AVSWAT-X) is a graphical user interface (DiLuzio et al., 2004) comprised of three key components:

(1) a preprocessor to generate the sub-basin topographic parameters and model input parameters, (2) functionality for editing input data and for executing the SWAT simulation, and (3) a postprocessor to view the graphical and tabular simulation results. There are existing databases for the United States that cover soils, crops, pesticides, fertilizers, tillage operations, and urban simulations. However, additional information can be added to these databases.

AVSWAT determines watershed border delineation and stream networks by using DEM as an input. The stream networks determine the set-up of the basin and automatically divide it into sub-basins. AVSWAT provides users with the functionality of adding or removing the sub-basins according to conditions. A series of hydrological response units (HRU), defined on the basis of each sub-basin, can be reclassified according to the joint layer of the soil and landuse maps. Each HRU represents grouped areas of a sub-basin containing similar land use and soil type.

\subsection{Strengths and weaknesses of SWAT}

The SWAT model has many advantages in hydrological modeling applications. The runtime estimation of the model ranges from a few minutes to less than one hour. The model is considered a long-term agricultural watershed model and is also suitable for yearly predictions of flow volumes and sediment (Borah et al., 2006). The disadvantages of using the SWAT model in hydrological applications include the high cost of setting up a simulation in large watersheds, the data requirements for the model to run, the time needed to process the data, difficulty determining the ideal set of parameters, and the problem of precisely estimating certain parameter values such as the flow of soil water and ground water into the stream channel (Borah et al., 2006).

\section{The Kinematic Runoff and Erosion Model: Description Model}

Kineros2 (K2) is a physically-based and distributed rainfall-runoff model that is also event-based and used mainly in arid and semi-arid catchments. This model is used to describe the processes of interception, dynamic infiltration, surface runoff, and erosion from watersheds characterized by a predominantly overland flow in small watersheds. In this model, the catchment is subdivided into a cascade of onedimensional overland flow planes and channels using topographic information. For each overland flow and channel, a set of parameters is assigned. Runoff is routed with an implicit finite difference solution of the kinematic wave equation (AlQurashi et al., 2008). The simulation process of the K2 model must start from upslope/upstream elements and progress to downstream elements to ensure the existence of upper boundary conditions (Semmens et al., 2008).

The K2 general approach starts with dividing the watershed into a "branching system" consisting of multiple channels and plane elements. For each plane, infiltration and roughness characteristics as well as the rainfall input may vary. Data on rainfall depth versus time can be provided for up to 20 sites within or near the basin. For each overland flow plane, the program calculates the difference between the rainfall rate and the infiltration rate for 5 to 15 nodes. There is an interaction between surface runoff routing and the infiltration component. This means that infiltration may continue even though rainfall has stopped because there is water remaining on the 
plane. Runoff is routed over each plane, through the channel system, and to the watershed outlet. Erosion can also be simulated if the erosion option is used. The system calculates the deposition and sediment transport and then routes the sediment through the system (Semmens et al., 2008).

\subsection{The use of Kineros in hydrological modelling in arid areas}

In Wadi Aday, Oman, Wheater (1981) used an old version of Kineros to analyze storms using a 15-min time step. The results obtained from the Kineros model were more enhanced than those gathered using a time-area approach. The reason for the improved results was the capability of representing non-linear effects of channel and overland flow due to the use of a physically-based model.

In a groundwater recharge analysis study, Mott Macdonald (1992) applied Kineros to Wadi Ahin in Oman. The study found that the calibrated parameters of Wadi Ahin should be transferred to nearby ungauged catchments due to the much wider range of volume errors on subsequent calibration over 16 events.

In another study conducted in the Walnut Gulch 6.4-km2 subcatchment, Yatheendradas et al. (2008) applied K2 to eight events to assess the utility of the model for flash flood forecasting and to identify the key sources of uncertainty. This study found that the principal cause of uncertainty were the discrepancies in recorded radar rainfall. For instance, the cumulative rainfall in one event varied between approximately $15 \mathrm{~mm}$ and 35 $\mathrm{mm}$, depending on the estimation method used. In addition, the authors reported that predicting an event using parameter sets identified based on other events resulted in significantly high uncertainty.

Another study applying the Kineros model was presented by Michaud and Sorooshian (1994b). The model was applied to the $150-\mathrm{km} 2$ Walnut
Gulch catchment. This study used six rainfall events for calibration, 24 events for validation, and 2-min resolution rainfall data. The results of the study were unsatisfactory due to the model's performance. For example, with four peaks being overestimated by more than $100 \%$; and the validation root mean square error (RMSE) for peak flows was $79 \%$ of the mean observed peak.

\subsection{Strengths and weaknesses of KINEROS2}

In terms of strengths and weaknesses, the K2 model has many advantages, such as high distribution accuracy of rainfall over watersheds. The model also provides a set of model parameters that are spatially distributed over the watershed and that work perfectly in predicting the rainfallrunoff process in small basins, including better resolution rainfall data and fewer time phases (Schaffner et al., 2010).

However, the weaknesses of K2 include low flow simulation because of the first dimensional (1-D) kinematic wave equations used, and K2 is only applicable for small catchments (Kalin and Hantush, 2003). Moreover, the model has limited capabilities to simulate best management practices (Borah et al., 2006).

\section{Description of the Identification of Unit Hydrograph and Component Flows from Rainfall, Evaporation, and Streamflow (IHACRES) Model}

The IHACRES model is a hybrid conceptualmetric model. It captures the strength aspects in both conceptual and metric models. It uses the simplicity of the metric model for the purpose of reducing the uncertainty associated with parameters that are inherent in hydrological models. At the same time, the model attempts to represent more details of the internal process, which is typical for a metric model (Croke et al., 2008).

The initial development of the IHACRES 
model was intended for applications to temperate catchments (Jakeman et al., 1990). The model was later modified to include applications to ephemeral streams (Ye et al., 1995, 1997; Schreider et al., 1996). According to Littlewood (2003), the main goal of using the IHACRES model is to describe catchment-scale hydrological behavior using a limited number of parameters. Thus, the model can be applied successfully in arid regions where hydrological datasets are very rare.

Recently, several versions of the IHACRES model have been developed and modified for the purpose of achieving a good simulation of ephemeral streams in arid regions. The structure of the model consists of a non-linear loss module, which converts actual rainfall into effective rainfall, and a linear module, which transfers effective rainfall to stream discharge (Croke et al., 2008).

The original structure of the IHACRES model used an exponentially decaying soil moisture index to convert rainfall into effective rainfall. Ye et al. (1997) developed an advanced version to improve the model performance in ephemeral catchments. This version is coded within IHACRES v2.0 and is given by the following formula:

where:

$$
u_{k}=\left[c\left(\phi_{k}-I\right)\right] p_{r_{k}}
$$

$u_{k}$ is the effective rainfall,

$r_{k}$ is the observed rainfall,

$c, I$, and $P$ are the parameters (mass balance, soil moisture index threshold, and non-linear response terms, respectively), and $\phi_{k}$ is the soil-moisture index.

Recent developments in the IHACRES rainfallrunoff model have increased its potential to model different aspects such as the effects of land use change on catchment response (e.g., Dye and Croke, 2003) and the ability to infer the hydrological response of ungauged catchments.
The modifications of most models are typically related to the non-linear loss module. Examples include developing a catchment moisture deficit (CMD) accounting system (Croke et al., 2004), simulating the effects of retention storages (Schreider et al., 1999), and linking a physicsbased groundwater discharge model (Sloan, 2000) with the IHACRES model (Croke et al., 2002), which has led to interactions between groundwater recharge and streamflow. A further development is a method based on estimating hydrographs directly from streamflow data without the need for rainfall data (Croke, 2004). Moreover, a new Java-based version of IHACRES has been incorporated into the Java component library (VisAD library). These components help visualize data, such as inputs and model outputs (Hibbard, 1998).

\subsection{The use of IHACRES in hydrological modelling in arid areas}

The IHACRES rainfall-runoff model has been successfully applied all over the world in arid and semi-arid catchments (e.g., Australia, Jordon, Oman, and many parts of Africa). IHACRES has been used in several studies, such as streamflow prediction in ungauged catchments and investigations of dynamic response characteristics (Kokkonen et al., 2003), land-cover effects on hydrological processes (Croke and Jakeman, 2004; Kokkonen et al., 2001), and physical catchment patterns (Sefton and Howarth, 1998).

In three low-yielding catchments in Australia, Ye et al. (1997) applied the IHACRES model using daily time-steps and continuous-time simulation. The purpose of their study was to compare the performance of three conceptual models (LASCAM, GSFB, and IHACRES) with different parameters. The authors concluded that IHACRES performed well; however, in the calibration and validation periods, the 22-parameter LASCAM performed better in 
general than the IHACRES system.

In another study in New South Wales, Australia, Croke et al. (2006) used IHACRES in a semidistributed model with a large catchment. The assignment of their study was to support the integrated assessment of water distribution. The catchment was distributed into 16 subcatchments according to their spatial variability of climate and hydrological responses. The study results were that in two subcatchments, the performance was insufficient due to a lack of rain gauges; however, in relation to the flow balances, the model performance was sufficient.

A calibrated version of the IHACRES model was able to clarify $96 \%$ of flow record variability by using monthly rainfall data from Mt. Kenaan, Israel, coupled with monthly flow data from the River Jordan gauging station (Whitehead et al., 2006). McIntyre et al. (2009) applied IHACRES to modelling flow peaks and volumes in the Wadi Ahin catchment in Oman. Their main task was to take an experimental approach to investigating the applicability of alternative versions of IHACRES. A sensitivity analysis was used to reduce IHACRES from a nine-parameter version (Ye et al., 1997) to five-parameter, four-parameter, and three-parameter versions, and the prediction performance of each was tested. The study concluded that the four-parameter version was ideal for predicting flow peak and that the threeparameter version was ideal for predicting flow volumes. Therefore, in general, the performance of each simple version of the IHACRES model was satisfactory; however, prediction uncertainty was high due to the variability of the effective parameter values over the events.

\subsection{Strengths and weaknesses of IHACRES}

The advantages and capabilities of the IHACRES model include the fact that the model parameters are described as simple and efficient; the system response identification works with a few years of data input (which is a smaller data requirement); the IHACRES model works with all watershed sizes; the dynamic response characteristics of watersheds are defined efficiently by the model; and the model is capable of retrieving changes in stream flow according to land-use changes in a watershed (Dye and Croke, 2003).

However, one disadvantage of the IHACRES model is that its ability to predict slow flows is better than its capabilities in predicting quick flows because upper flows tend to be undersimulated. The model works more effectively in small catchments than large ones in terms of generating useful flow predictions, and it is suitable for predicting the effect of land-use changes on low flows (Dye and Croke, 2003).

\section{Description of the Hydrologic Engineering Center-Hydrologic Modelling System Model}

The Hydrologic Engineering Center-Hydrologic Modeling System (HEC-HMS) is a hydrological modeling system designed and developed by the United States (US) Army Corps of Engineers Hydrologic Engineering Center (HEC). The model is intended to simulate precipitationrunoff processes of watershed systems. The system has the capability to model a wide range of geographical areas, including large river catchments and small urban or natural watersheds (Verma et al., 2010). Furthermore, the model has been widely applied to simulate and forecast stream flows for humid, tropical, sub-tropical, and arid watersheds (Abushandi, 2011). It consists of four main components: a system used for storing and managing large amounts of data, analytical models with capabilities to calculate overflow and channel routing, a sophisticated graphical display that shows the hydrologic system and its components, and a tool used to display and report output (Moghadas, 2009).

Moreover, the HEC-HMS model encapsulates multiple functions, such as loss estimation, 
runoff transformation, open-channel routing, meteorological data analysis, rainfall-runoff simulations, and parameter estimation. Each component of the runoff process is represented by separate models. Examples of these models include models for computing runoff volume, models for direct runoff, and models for baseflow. Moreover, the basin, meteorological, and control flow models are combined in each model with a run option to obtain results. System data are stored in two different models: the basin model and the meteorological model. The system connectivity and physical data describing the watershed are located in the basin model. Data for precipitation and evapotranspiration, which are required to simulate watershed processes, are stored in the meteorological model (Verma et al., 2010).

While the HEC-HMS has the ability to model infiltrations from the land's surface, the system cannot model storage and water movement vertically within the soil layer. Instead, it works by combining the near-surface and overland flow and models it as a direct runoff (Verma et al., 2010).

\subsection{HEC Geo-HMS}

A Geo-Spatial Hydrologic Modeling Extension for the ARC-GIS was developed by the US Army Corps of Engineers HEC. The extension is fully equipped with a simple interface, a menu, tools, and bottoms for the purpose of generating hydrologic inputs for the direct use of the modeling ystem, the HEC-HMS. Therefore, the extension can be used effortlessly by engineers and hydrologists with limited experience (GeoHMS, 2003).

The Geo-HMS provides a sub-basin delineation and manipulation tool. This tool has the capability to create a background map containing the stream alignments and sub-basin boundaries. For example, the system can supply point data sets as desired outlets to delineate sub-basins.
Furthermore, it can represent water movement through the sub-basins by creating a lumped basin model containing hydrologic elements and their connectivity. Examples of Geo-HMS capabilities include creating a grid-cell parameter file and a distributed basin model, generating a table of the physical characteristics of watersheds and streams, analyzing DEM data, computing the $\mathrm{CN}$ value of sub-basins, and generating the meteorological model and control specifications (Geo-HMS, 2003).

\subsection{The use of the HEC-HMS model in hydrological modelling in arid areas}

In Jordon's AL-Zaraqa basin, Al-Abed et al. (2005) applied the HEC-HMS with another model to discover the advantages of using GIS-based hydrological models as water management tools. Their study showed that the HEC-HMS model provided more suitable results than the other model. Yener et al. (2006) selected the Yuvacik Basin in Turkey as a study area for simulations and runoff scenarios using intensity duration frequency curves for modeling studies applied by the HEC-HMS model.

In a section of the Qara Ajaq River in the Fars Province of Iran, Purreza et al. (2007) used hydraulic models and the HEC-GEOHMS extension to estimate and determine the zone of water flood so as to identify factors influencing the flood-susceptibility potential of basins and their zoning in terms of flood-susceptibility potential. Moreover, in the Kan watershed in Iran, Ghanbarpour (2007) employed the HEC-HMS model to simulate the watershed response to any changes from structural and non-structural flood control measures and synchronized hydrograph analysis. Another study by Nasri et al. (2011) in Iran's Sheikh Bahaei Dam basin used the HECHMS model to simulate the flow of rainfallrunoff processes common to that area. The results of their study showed that the HEC-HMS model 
accurately determined the areas playing the greatest role in flood development.

Zorkeflee et al. (2009) conducted a study in the Sungai Kurau Basin using the GIS and HECHMS models for catchment management. They also analyzed the impact of land-use changes on the hydrologic behavior of the basin. In the Baitarani catchment in India, Verma et al. (2010) indicated the suitability of the HEC-HMS model for simulating runoff flow after using the HECHMS and WEPP models in their study.

Dastorani et al. (2011) evaluated the HECHMS model for its ability to predict flooding and to model rainfall-runoff processes in the Toroq watershed in Iran. Their study indicated the strengths of the HEC-HMS model in rainfallrunoff simulations in ungauged catchments. However, the main parameters affecting the results were the curve number $(\mathrm{CN})$ and initial loss. Therefore, these parameters must be correctly estimated during the calibration process to ensure the most accurate results.

\subsection{Strengths and weaknesses of the HEC- HMS model}

The main advantages of the HEC-HMS model include runoff, channel routing, and water control structures, which are the main components of the model. The model has the capabilities to be applied to different watershed sizes, shapes, and characteristics, and it uses a simple method to manage data in terms of what is entered, organized, accessed, and visualized (Beckers et al., 2009).

The limitations of HEC-HMS are that the watershed process simulation is an experimental method; the model has limited capabilities for implementation in river processes; and specific conditions apply, such as a certain type of topography (e.g., gradual topography), when modeling watersheds of any size (Beckers et al., 2009).

\section{SCS-The Runoff Curve Number Method}

The RCN is an efficient method designed to approximate the amount of runoff generated from a rainfall event in a certain area. Initially, the method was developed by the USDA Natural Resources Conservation Service, formerly called the Soil Conservation Service (SCS), in 1954. The RCN, which is also known as SCS, is an experimental parameter used in hydrology to estimate the runoff or infiltration generated by rainfall (Ponce et al., 1996). Ritzema (1994) explained the use of the RCN in drainage basins: The method is used to predict direct runoff depth from rainfall depth; it then provides an index that illustrates the characteristics of the runoff response. The RCN depends on several factors such as the area's hydrologic soil group, land use, treatment, and hydrologic condition (Ponce et al., 1996) and antecedent soil moisture conditions in the drainage basin (Ritzema, 1994).

The RCN depends on two factors - the initial abstraction and actual retention. The initial abstraction starts with the accumulation of rainfall. This is represented by interception, depression storage, and infiltration before the start of runoff. Actual retention starts after runoff has started, and additional rainfall is lost in the process of infiltration. The basic mathematical assumption of the SCS-CN method is that the ratio of actual soil retention after runoff begins to potential maximum retention is equal to the ratio of direct runoff to potential maximum runoff. After algebraic manipulation and a simplifying assumption, the previous relationships can be represented in this mathematical equation:

where:

$$
Q=\frac{(P-0.2 S)^{2}}{P+0.8 S^{\prime}}
$$

$Q$ is runoff ([L]; in),

$P$ is rainfall ([L]; in),

$S$ is the potential maximum soil moisture retention after runoff begins ([L]; in), 
Ia is the initial abstraction ([L]; in) or the amount of water before runoff, such as infiltration, or rainfall interception by vegetation, and $\mathrm{Ia}=0.2 \mathrm{~S}$.

The RCN, $C N$, is then related as

$$
S=\frac{1000}{C N}-10 .
$$

$\mathrm{CN}$ ranges from 30 to 100 ; lower numbers indicate low runoff potential, while larger numbers show an increase in runoff potential.

\subsection{The use of the runoff curve number method in geographic information systems- based hydrological modelling}

With the rapid development in technology, the ArcGIS software can give a precise calculation of the $\mathrm{CN}$ in the RCN method. Zhan and Huang (2004) explained the development and application of the $\mathrm{ArcCN}$ runoff tool. For a storm event within a watershed, the $\mathrm{ArcCN}$ runoff tool can be used to determine $\mathrm{CNs}$ as well as to estimate runoff or infiltration.

There is usually a loss of some detailed spatial variation within the watershed during runoff calculation, and the $\mathrm{ArcCN}$ runoff tool is designed to overcome this problem. Some of the features in the $\mathrm{ArcCN}$ tool include its ability to maintain irregular boundaries by using polygons of different shapes and a built-in database to help determine $\mathrm{CN}$ based on soil- and land-use data. The program can help to manage and design the process of estimating future discharges, hydraulic structuring, and projects as well as for predicting watershed responses to urbanization.

Zhan and Huang (2004) suggested a number of aspects that would improve the $\mathrm{ArcCN}$ tool predictions, such as the implementation of a rainfall time series and consideration of factors such as dry and wet antecedent moisture conditions (for CN parameters). A GIS-related method was developed by Braun et al. (2003) to describe groundwater recharge areas. His methodology was used in Waukesha County, Wisconsin, to observe recharge areas. The methodology used precipitation, temperature, soil, and land-cover data to generate percolation, surface runoff, and root-zone water capacity maps. By combining land-use and soil information, differences in surface runoff potential were efficiently determined. The $\mathrm{CN}$ values in this method were assigned to distinct regions based on their unique soil and land cover rather than assigning a single $\mathrm{CN}$ to an entire basin. Surface runoff potential maps were produced according to $\mathrm{CN}$ rankings. A high ranking indicated low surface runoff areas, whereas a low ranking indicated high surface runoff areas. The recharge potential of different areas was then used to combine and rank maps for percolation, surface runoff, and root-zone water capacity.

Another study utilizing a GIS-based approach and employing the $\mathrm{CN}$ method was performed by Dawod et al. (2011) and was conducted in the Makkah metropolitan area in the southwest of Saudi Arabia. The purpose of the study was to develop a GIS-based method to map and quantify flood assessment measures. Several topographic, metrological, geological, and land-use datasets were integrated in a GIS environment that used the $\mathrm{CN}$ flood modelling method. The study showed that several factors affect total flood volume, such as the catchment area, the length of the basin stream, and the peak discharge. Moreover, the study found that the higher the $\mathrm{CN}$ value, the higher the runoff and flood hazards.

\section{Conclusion}

This article has reviewed many studies related to GIS and RS technology, along with their data and applications, in order to analyze their role in aiding hydrological modelling in arid regions. In particular, the review focused on several fundamental aspects of hydrological modelling, such as hydrological and watershed models, digital elevation model data, land-use/cover data, 
soil data, rainfall data, the SWAT model, the KINEROS2 model, the IHACRES model, the HEC-HMS model, and the RCN method.

In arid areas, water is considered to be a vital resource. Several studies have been carried out to develop hydrological models in these areas. However, there are several issues associated with hydrological modelling in arid regions that have been detected throughout this literature review: (1) the limited nature of hydrological data, (2) the lack of high-quality observations, (3) difficulty developing suitable hydrological models due to the lack of advanced technology in most arid regions, (4) the shortage and variability of rainfall, (5) unexpected flash flood events, and (6) the fact that most hydrological models are designed for humid areas. These issues cause problems for researchers, water resource management, and those developing GIS-based hydrological models.

Arid areas require more attention from researchers in order to overcome the obstacles in hydrological modelling. For example, researchers should consider new methods for determining spatial rainfall and infiltration from transient flows that come from flash floods. In arid areas, RS data can be used for simulating events instead of using gauged data. Observational data can also be improved by creating multiple measurement stations in affected areas.

\section{References}

*Abushandi, E., H., (2011a) Rainfall-Runoff Modeling in Arid Areas, Faculty for Geosciences, Geotechnique and Mining of the Technische Universität Bergakademie Freiberg. p. 26-36.

*Abushandi E., Merkel B. (2011b) Modelling rainfall runoff relations using HEC-HMS and IHACRES for a single rain event in arid region, Jordan. Water Resources Management Journal

*Aisha Al-Qurashi, Neil McIntyre, Howard Wheater, and Carl Unkrich. Application of the kineros2 rainfall-runoff model to an arid catchment in oman. Journal of Hydrology, 355(1-4):91 - 105, 2008.

*Al-Abed N, Abdulla F, Abu Khyarah A (2005) GIS-hydrological models for managing water resources in the Zarqa River basin. Environmental Geology 47:405-411.

*Al Mulla, M.M., 2005, Application of a hydrological model in a data-poor arid region catchment: a case study of Wadi Ham, United Arab Emirates, Cranfield University, p: $97-101$.

*Al-Qurashi, A., N. McIntyre, H. Wheater, and C. Unkrich, 2008, Application of the Kineros2 rainfall-runoff model to an arid catchment in Oman: Journal of Hydrology, v. 355, p. 91-105.

*Al-Turbak AS, 1996, Geomorphoclimatic peak discharge model with a physically based infiltration component. Journal of hydrology 176:1-12.

*AMS, 2000. Definition of a flash flood from the American Meteorological Society Glossary of Meteorology.

*Arnold, J. G., R. Srinivasan, R. S. Muttiah, and J. R. Williams, 1998, Large area hydrologic modeling and assessment part I: Model Development 1: JAWRA Journal of the American Water Resources Association, v. 34, p. 73-89.

*Arnold, J.G., Williams, J.R., Nicks, A., and Sammons, N.B. 1990. SWWRB-A basin Scale Simulation Model. College Station: Texas A\&M Press.

*ASCE, 1999. GIS Modules and Distributed Models of the Watershed. A report by the ASCE Task Committee on GIS Modules and Distributed Models of Watershed, P.A. DeBarray and R.G. Quimpo (Eds.), Reston, VI.

*Beckers, J.; Smerdon, B.; Wilson, M. (2009). Review of hydrologic models for forest management and climate change applications in British Columbia and Albert. Available: http:// www.forrex.org/sites/default/files/forrex 
series/FS25.pdf. Last accessed 20th Jul 2012.

*Beven, K., 1984, Infiltration into a class of vertically non-uniform soils: Hydrological Sciences Journal-Journal Des Sciences Hydrologiques, v. 29, p. 425-434.

*Beven, K., 1995, Linking Parameters across Scales - Subgrid Parameterizations and ScaleDependent Hydrological Models: Hydrological Processes, v. 9, p. 507-525.

*Beven, K., 2001, Rainfall-runoff modelling: the primer: Chichester, John Wiley \& Sons, Ltd, $355 \mathrm{p}$.

*Bhaskar, N.R., James, W.P. and Devulapalli, R.S. (1992). Hydrologic parameter estimation using geographic information system. J. Water Resour. Plann. Manag., ASCE, 118(5): 492512.

*Borah, D. K., G. Yagow, A. Saleh, P. L. Barnes, W. Rosenthal, E. C. Krug, and L. M. Hauck. 2006. Sediment and nutrient modeling for TMDL development and implementation. Trans. ASABE 49(4): 967-986.

*Boughton, W., and F. Chiew, 2007, Estimating runoff in ungauged catchments from rainfall, PET and the AWBM model: Environmental Modelling \& Software, v.22, p. 476-487.

*Braun, G.M., N.S. Levine, S.J. Roberts, and A.N. Samel. 2003. "A Geographic Information Systems Methodology for the Identification of Groundwater Recharge Areas in Waukesha County, Wisconsin." Environmental and Engineering Geoscience 9(3): 267-278.

*Brennen, J. (1994). Developing an integrated, multi-purpose geographic information system. Public Works, 125(9): 43-46.

*Bronstert, A., 2004, Rainfall-runoff modelling for assessing impacts of climate and land-use change: Hydrological Processes, v. 18, p. 567-570.

*Chapter 4 in: H.P.Ritzema (Ed.), Drainage
Principles and Applications, Publication 16, second revised edition, 1994, International Institute for Land Reclamation and Improvement (ILRI), Wageningen, The Netherlands. ISBN 9070754339 .

*Chow, V. T. (ed.) (1964) Handbook of Applied Hydrology, McGraw-Hill Book Company, New York, USA.

Chow, V. T., Maidment, D. R. \& Mavs, L. W. (1988) Applied Hydrology, McGraw-Hill, New York, USA.

*Croke, B.F.W. 2004, 'A technique for deriving the average event unit hydrograph from streamflow-only data for quick-flowdominant catchments', in preparation.

*Croke, B.F.W., A.B. Smith and A.J. Jakeman 2002, 'A One-Parameter Groundwater Discharge Model Linked to the IHACRES Rainfall-Runoff Model'. In: A. Rizzoli and A. Jakeman (eds), Proceedings of the 1st Biennial Meeting of the International Environmental Modelling and Software Society, University of Lugano, Switzerland, vol I, pp 428-433.

*Croke BFW, Andrews F, Jakeman AJ, Cuddy SM, Luddy A (2006) IHACRES classic plus: A redesign of the IHACRES rainfall-runoff model. Environmental Modelling \& Software 21:426-427.

*Croke, B.F.W. and A.J. Jakeman 2004, 'A Catchment Moisture Deficit module for the IHACRES rainfall-runoff model', Environmental Modelling and Software, vol 19, pp 1-5.

*Croke, B.F.W., Jakeman, A.J., 2008. Use of the IHACRES rainfall-runoff model in arid and semi arid regions. In: Wheater, H.S., Sorooshian, S., Sharma, K.D. (Eds.), Hydrological Modelling in Arid and Semi-arid Areas. Cambridge University Press, Cambridge, pp. 41-48.

*Das, S.N. Tripathi, M.P. Shrivastava, P.K. 
(2004): Hydrological Modeling of a Small Watershed Using Satellite Data and GIS Technique, Journal of the Indian Society of Remote Sensing, Vol. 32, No.2, pp.145 157.

*Dastorani, M. T., Khodaparast, R., Talebi, A., Vafakhah, M., Dashti, J., 2011. Determination of the Ability of HEC-HMS Model Components in Rainfall-run-off Simulation. Research Journal of Environmental Sciences, 5: 790-797.

*Dawod G, Mirza M, Al-Ghamdi K (2011) GIS-based spatial mapping of flash flood hazards in Makkah city, Saudi Arabia. J Geogr Inf Syst 3(3):217-223.

*De Pauw E., Göbel W. \& Adam H. (2000) Agrometeorological aspects of agriculture and forestry in the arid zones. Agricultural and Forest Meteorology, 103, 43-58.

*Dewan AM, Nishigaki M, Komatsu M (2004) DEM based flood delineation in Dhaka city, Bangladesh.J Facul Environ Sci Technol 9(1):99-110.

*DHI, 1993, Mike11, A microcomputer-based modelling system for rivers and channels, User and reference manual, in D. H. Institute, ed., Hørsholm, Denmark.

*Di Lizio M., J.G. Arnold, and R. Srinivasan, 2004. Integration of SSURGO Maps And Soil Parameters Within A Geographic Information System And Nonpoint Source Pollution Model. J. Soil Water Conserv. 59(4): 123-133.

*Dye P.J. and B. F. W. Croke 2003, 'Evaluation of streamflow predictions by the IHACRES rainfall-runoff model in two South African catchments', Environmental Modelling and Software, vol 18, pp 705-712.

*Engman, E. T. (1986) Hydrologie research before and after AgRISTARS. IEEE Trans. Geosci. Remote Sens. GE-14(1), 5-11.

*Fadil, A. Rhinane, H., Kaoukaya,A. Kharchaf, Y. and Bachir, O. A., 2011, Hydrologic Modeling of the Bouregreg Watershed (Morocco) Using
GIS and SWAT Model, Journal of Geographic Information System 3, 279-289.

*Frederickson, K. (1993). GIS-Hydrologic model interface for flood prediction and assessment. Arlington, Va.: Triservice CADD/ GIS Training Symposium.

*Fresco LO (1994) Imaginable futures, a contribution to thinking about land use planning (eds Fresco LO, Stroosnijder L, Bouma J, van Keulen H), pp. 1-8. John Wiley and Sons, Chichester.

*G. Dawod, M. Mirza and K. Al-Ghamdi, "Assessment of Several Flood Estimation Methodologies in Makkah Metropolitan Area, Saudi Arabia," Under Review, Arabian Journal of Geosciences, 2011.

${ }^{*}$ G. W. KITE \& A. PIETRONIRO (1996): Remote sensing applications in hydrological modeling, Hydrological Sciences Journal, 41:4, 563-591.

*Garbrecht, J., and L.W. Martz, 2000. Digital elevation model issues in water resources modeling. Hydrology and Hydraulic Modeling Support with Geographic Information System (D. Maidment and D. Djokic, editors), ESRI Press, Redlands, California, pp. 1-28.

*Ghanbarpour M. Reza. (2007). Evaluation of flood mitigation alternatives using hydrological modeling. J. Appl. Sci. Environ. Manage. 11 (4), p113-117.

*Green, W. H., and G. A. Ampt. 1911. Studies on soil physics. J. Agric. Sci. 4(1): 1-24.

*Gunduz, O. and Aral, M.M. (2003c). "Hydrologic modeling of the lower Altamaha river basin." In Proceedings of the 2003 Georgia Water Resources Conference, edited by K.J. Hatcher, Athens, Georgia, USA.

*Hibbard, W. 1998, 'VisAD: Connecting people to computations and people to people', Computer Graphics vol 32, pp 10-12. 
*Jain, M. K., Kothyari, U. C., and Ranga-Raju, K. (2004). A GIS based distributed rainfallrunoff model. Journal of Hydrology, 299(1-2), 107-135.

*Jakeman, A. J., and G. M. Hornberger, 1993, How much complexity is warranted in a rainfallrunoff model: Water Resources Research, v. 29, p. 2637-2649.

*Jakubauskas, M.E., Whistler, J.L., Dillworth, M.E. and Martinko, E.A. (1992). Classifying remotely sensed data for use in an agricultural nonpoint source pollution model. J. of Soil and Water Cons., 47(2): 179-183.

*Jenson, S. K. and Domingue, J. O.: 1988, 'Extracting topographic structure from digital elevation data for geographic information systems analyses, Photogramm. Eng. Remote Sens. 54(11), 1593-1600.

*Johnson, L.E. (1989). A digital map based hydrologic modelling system. Photogramm. Engg. and Remote Sensing, 55(6): 911-917.

*Kalin, L., and M. M. Hantush. 2003. Evaluation of sediment transport models and comparative application of two watershed models. EPA/600/R-03/139. Cincinnati, Ohio: USEPA, National Risk Management Research Laboratory.

*Knisel, W. G. (ed). 1980. CREAMS: A field scale model for chemicals, runoff, and erosion from agricultural management systems. U.S. Department of Agriculture, Science and Education Administration, Conservation Research Report no. 26.

*Knebl, M. R., Yang, Z.-L., Hutchison, K., and Maidment, D. R. (2005). Regional scale flood modeling using NEXRAD rainfall, GIS, and HEC-HMS/RAS: a case study for the San Antonio River Basin Summer 2002 storm event. Journal of Environmental Management, $75,325-336$.

*Kirkby, M. J. (ed.) (1978) Hillslope
Hydrology, John Wiley, New York, USA, 325363.

*Kokkonen, T., A.J. Jakeman, P.C. Young and H.J. Koivusalo 2003, 'Predicting daily flows in ungauged catchments: model regionalization from catchment descriptors at the Coweeta Hydrologic Laboratory, North Carolina', Hydrological Processes, vol 17, pp 2219-2238.

*Kokkonen, T., Koivusalo, H. \& Karvonen, T. 2001 A semi-distributed approach to rainfallrunoff modeling - a case study in a snow affected catchment. Environ. Model. Soft. 16(5), 481-493.

*Kouwen, N., Soulis, E.D., Pietroniro, A., Donald, J. and Harrington, R.A. (1993). Grouped response units for distributed hydrologic modeling. J. Water Resour. Plann. and Manag., ASCE, 119(3): 289-305.

*Lee, M.T. and Terstriep, M.L. (1991). Applications of GIS for water quality modelling in agriculture and urban watershed. In: Hydr. Engg., Proc., 1991, Nat. Conf., ASCE, New York, NY, pp. 961-965.

*Leonard, R. A., W. G. Knisel, and D. A. Still. 1987. GLEAMS: Groundwater loading effects of agricultural management systems. Transactions of the ASAE 30(5): 1403-1418.

*Littlewood, I.G., B.F.W. Croke, A.J. Jakeman and M. Sivapalan 2003, 'The role of 'top-down' modelling for Prediction in Ungauged Basins (PUB)', Hydrological Processes, vol 17, pp 1673-1679.

*Lu ,M., Koike,T. and Hayakawa,N. (1996)"A distributed hydrological modeling system linking GIS and hydrological models", HydroGIS 95: Application of Geographic Information Systems in Hydrology and water Resources Management (Proc. Vienna Conference April IAHS Publ.No. 235ppp.141148.

*Maidment, D.R. (1993). GIS and Hydrologic 
modeling. In: Environmental Modeling with G1S, M.F. Goodchild, B.O. Parks and L.T. Steyaert (eds.), New York: Oxford Univ. Press.

*Mark. D. M. 1975. 'Computer analysis of topography: B comparison of terrain storage methods'. Gcoyra/wka Annulrr, 57A,I 79- 188.

*McConnell W, Moran EF (2001) Meeting in the Middle: The Challenge of MesoLevel Integration. LUCC Focus 1 Office, Anthropological Center for Training and Research on Global Environmental Change, Indiana University.

*McIntyre, N., and A. Al-Qurashi, 2009, Performance of ten rainfall-runoff models applied to an arid catchment in Oman: Environmental Modelling \& Software, v. 24, p. 726-738.

*Michaud J, Sorooshian S. 1994. Comparison of simple versus complex distributed runoff models on a midsized semiarid watershed. Water Resources Research 30(3): 593-605.

*Moghadas, S. (2009). Long-term Water Balance of an Inland River Basin in an Arid Area, North-Western China. Division of Water Resources Engineering, Department of Building and Environmental Technology, Lund University. Chpter 2. p10-13.

*Moon, J., Srinivasan, R., and Jacobs, J. H. (2004). Stream flow estimation using spatially distributed rainfall in the Trinity River basin, Texas. Transactions of the American Society of Agricultural and Biological Engineers, 47(5), 1445-1451.

*Moore, 1. D. 1988. 'A contour-based terrain analysis program for the environmental sciences (TAPES)', Trans. Am, Geo phys.Uni on. 69,345 .

*Moore, I. D., R. B. Grayson and A. R. Ladson, (1991), "Digital Terrain Modelling: A Review of Hydrological, Geomorphological, and Biological Applications," Hydrological
Processes, 5(1): 3-30.

*Mott Macdonald, 1992. Groundwater recharge schemes for Saham-Sohar area - data analysis report. Sultanate of Oman, Ministry of Agriculture and Fisheries, Internal Report, May 1992, 48p. Nouh, M., 2006. Wadi flow in the Arabian Gulf states. Hydrological Processes 20, 2393-2413.

*Nasri, M., Soleimani, F., Sardoo, Katani. M. (2011) Simulation of the Rainfall-Runoff Process Using of HEC-HMS Hydrological Model. World Academy of Science, Engineering and Technology. 78, p548-551.

*National Weather Service, 2007a: National Weather Service Instruction 10-922. [Available on-line at:http://www.nws.noaa.gov/directives/ sym/pd01009022curr.pdf].

*Neitsch, S. L., Arnold, J. G., Kiniry, J. R.,Williams, J.R., and King, K.W.: Soil and water assessment tool theoretical documentation: version 2000, Texas water resources institute, College station, Texas, USA, 2002.

*NOAA. (2008). Hazards/Climate Extremes.

*Ogden, F. L., Garbrecht, J., DeBarry, P.A. and Johnson, L. E. (2001). "GIS and distributed watershed models II: Modules, Interfaces, and Models", Journal of Hydrologic Engineering, ASCE, 6 (6), pp. 515-523.

*O'Callaghan, J. F. and Mark, D. M.: 1984, 'The extraction of drainage networks from digital elevation data', Comp. Vis. Graph. Image Process. 28, 323-344.

*O'Loughlin, E. M.: 1986, 'Prediction of surface saturation zones in natural catchments by topographic analysis', Water Resource Res. 22, 794-804.

*Ouessar, M., A. Bruggeman, F. Abdelli, R.H. Mohtar, D. Gabriels, and W.M. Cornelis. 2009. Modelling water-harvesting systems in the arid south of Tunisia using SWAT. Hydrology and Earth System Sciences 13:2003-2021. 
*Panuska, J. C., Moore, 1. D., and Kramer, L. A. 1990. 'Terrain analysis: integration into the Agricultural Nonpoint Source Pollution (AGNPS) model', J. Soil and Water Conserv., in press.

*Peucker, T. K., Fowler, R. J., Little, J. J., and Mark, D. M. 1978. 'The triangulated irregular network', Proc. Auto Carto If/, Am. Congress on Surveying and Mapping, Fallschurch, Virqnia, 516-540.

*Perrin, C., C. Michel, and V. Andréassian, 2003, Improvement of a parsimonious model for streamflow simulation: Journal of Hydrology, v. 279 , p. $275-289$.

*Pilgrim, D. H., T. G. Chapman, and D. G. Doran, 1988, Problems of Rainfall-Runoff Modeling in Arid and Semiarid Regions: Hydrological Sciences Journal-Journal Des Sciences Hydrologiques, v. 33, p. 379-400.

*Ponce, V. M. and R. H. Hawkins. 1996. Runoff curve number: Has it reached maturity? Journal of Hydrologic Engineering 1(1):11-19.

*Purreza, M. Shahri, 2007, flood mapping using GIS, study design: a part of Ghareaghaj river in Fars province, Iran, GIS conference, $p$ 24, Tehran.

*Quinn, P., Beven, K., Chevallier, P. and Planchon, O.: 1991, 'The prediction of hillslope flow paths for distributed hydrological modelling using digital terrain models', Hydrol. Process. 5(1), 59-79.

*Rango, A. (1994). Application of remote sensing methods to hydrology and water resources. J. Hydro. Sci., 39(4): 309-319.

*Reed, S., J. Schaake, and Z. Y. Zhang, 2007, A distributed hydrologic model and threshold frequency-based method for flash flood forecasting at ungauged locations: Journal of Hydrology, v. 337, p. 402-420.

*Ross, M.A. and Tara, PD. (1993). Integrated hydrologic modelling with geographic information systems. J. of Water Resour. Plann. and Manag., ASCE, 119(2):129-140.

*Scharffenberg, W., and M. Fleming, 2010, Hydrologic modeling system HEC-HMS v3.2 user's manual.: Davis, USA, USACE-HEC.

*Semmens, D.J., D.C. Goodrich, C.L. Unkrich, R.E. Smith, D.A. Woolhiser, and S.N. Miller (2008). KINEROS2 and the AGWA modeling framework; in Wheater, H., S. Sorooshian, and K.D. Sharma, (Eds.) Hydrological Modelling In Arid and Semi-Arid Areas, Cambridge University Press, New York, 206pp.

*Schaffner, M., C.L. Unkrich, D.C. Goodrich, 2010: Application of the KINEROS2 site specific model to south-central NY and northeast PA: forecasting gaged and ungaged fast responding watersheds. NWS Eastern Region Technical Attachment, No. 2010-01

*Schmidt, F. and Persson, A.: 2003, 'Comparison of DEM data capture and topographic wetness Indices' Precision Agricul. 4, 179-192.

*Schneider, K., Ketzer, B., Breuer, L., Vach'e, K. B., Bernhofer, C., and Frede, H.-G.: Evaluation of evapotranspiration methods for model validation in a semi-arid watershed in northern China, Adv. Geosci., 11, 37-42, 2007, http://www.adv-geosci.net/11/37/2007/.

*Schreider, S.Y., Jakeman, A.J., Pittock, A.B., 1996. Modelling rainfall-runoff from large catchment to basin scale: the Goulburn Valley, Victoria. Hydrological Processes 10 (6), 863876.

*Sefton, C. E. M. \& Howarth, S. M. 1998 Relationships between dynamic response characteristics and physical descriptors of catchments in England and Wales. J. Hydrol. 211(1-4), 1-16.

*Shadeed, S., and M. Almasri, 2010, Application of GIS-based SCS-CN method in West Bank catchments, Palestine: Water 
Science and Engineering, v. 3, p. 1-13.

*Sharpley, A. N., and J. R. Williams, eds., 1990: EPIC-Erosion Productivity Impact Calculator, 1. Model documentation. U.S. Department of Agriculture, Agricultural Research Service, Tech. Bull. 1768.

*Singh, V. P., and Woolhiser, D. A. (2002). Mathematical modeling of watershed hydrology. Journal of Hydrologic Engineering, 7(4), 270-292.

*Sloan, W.T. 2000, 'A physics-based function for modelling transient groundwater discharge at the watershed scale', Water Resources Research, vol 36, pp 225-241.

*Srinivasan, R. and Engel, B.A. (1994). A spatial decision support system for assessing agricultural nonpoint source pollution. Water Resour. Bull., AWRA, 30(3):441-452.

*Tim, U.S. (I 995). Emerging technologies for hydrologic and water quality modeling research. Trans. of the ASAE, 39(2): 465-476.

*Tim, U.S., Milner, M. and Majure, J. (1992). Geographic information systems/simulation model linkage: Processes, problems and opportunities. ASAE paper No.92-3610, ASAE, St. Joseph, Michigan.

*Tribe, A. 1992. Automated Recognition of Valley Heads from Digial Elevation Models. Earth Surface Processes \& Landforms, 16(1):33-49.

USDA-SCS. 1985. National Engineering Handbook, Section 4 - Hydrology. Washington, D.C.: USDA-SCS.

*Verma, A.K., M.K. Jha and R.K. Mahana, 2010. Evaluation of HEC-HMS and WEPP for simulating watershed runoff using remote sensing and geographical information system. Paddy Water Environ., 8: 131-144.

*Vieux, B. E. (2004). Distributed hydrologic modeling using GIS. Dordrecth, The
Netherlands: Kluwer Academic Publishers.

*Wheater, H.S., 1981. Northern Oman Flood Study. Imperial College, London, p. 270.

*Wheater, H. S., Sorooshian, S. \& Sharma, K. D. 2008 Hydrological Modeling in Arid and Semi-arid Areas, Cambridge University Press, Cambridge.

*Whitehead, P., Wade, A. \& Flynn, N. 2006 Water life and civilization project, second year report.

Williams, J.R., C.A. Jones, and P.T. Dyke. 1984. A Modeling Approach to Determining the Relationship between Erosion and Soil Productivity. Transactions of the ASAE 27:129144.

*Wilson JP, Mitasova H, Wright DJ. 2000. Water resource applications of Geographic Information Systems. URISA Journal 12(2): 61-79.

*WMO, 2007a: Guidance on Flash Flood Management - Recent Experience from Central and Eastern Europe. APFM, Geneva, Switzerland: World Meteorological Organization. Available at:http://www.apfm. info/pdf/pilot_projects/APFM-CEE-Synthesis web.pdf (last accessed 18 May 2012).

*Wood, E. F, Sivapalan, M. \& Beven, K. (1990) Similarity and scale in catchment storm response. Rev. Geophys. 28(1), 1-18.

*Yatheendradas, S., Wagener, T., Gupta, H., Unkrich, C.L., Goodrich, D.C., Schaffner, M., Stewart, A., 2008. Understanding uncertainty in distributed flash flood forecasting for semiarid regions. Water Resources Research, in press, doi:10.1029/2007WR005940.

*Ye, W., Bates, B.C., Viney, N.R., Sivapalan, M., Jakeman, A.J., 1997. Performance of conceptual rainfall-runoff models in lowyielding ephemeral catchments. Water Resources Research 33 (1), 153-166. 
*Ye, W., Jakeman, A.J., Barnes, C.J., 1995. A parametrically efficient model for prediction of streamflow in an Australian benchmark catchment with complex storage dynamics. Environment International 21 (5), 475-758.

*Yener, M.K., A.U. Sorman and T. Gezgin, 2006. Modeling studies with HEC-HMS and runoff scenarious in Yuvacik Basin, Turkiye. http://www.dsi.gov.tr/english/congress2007/ chapter_4/123.pdf.

*Young, R.A., Onstad, C.A., Bosch, D.D. and Anderson, W. P. (1987). AGNPS: An agricultural nonpoint source pollution model: A large watershed analysis tool. USDA Cons. Res. Rept. 35, pp.77.

*Yu P, Jeng Y (1997) A study on grid based distributed rainfall runoff models. Water Resources Management 11: 83-99.

*US Army Corp of Engineers, Hydrologic Center, 2006, Geospatial Hydrologic Modeling Extension, HEC-GeoHMS, User's Manual (version 1.1)

*Zhan, X. and Huang, M. L. 2004. ArcCNRunoff: an ArcGIS tool for generating curve number and runoff maps. Environ. Model. Softw. 19(10): 875-879.

*Zhang, H., Haan, C.T. and Nofziger, D.L. (1990). Hydrologic modeling with GIS: An overview. Applied Engg. In Agriculture, 6(4): 453-458.

*Zorkeflee, A.H., H. Nuramidah and S.Y. Mohd, 2009. Integrated river basin management (IRBM): Hydrologic modelling using HEC-HMS for sungai kurau basin, Perak. Proceedongs of the International Conference on Water Resources, (ICWR'09), River Basin Management Society, pp: 1-7. 